\title{
Upaya Multinational Corporation (MNC) Dalam Mengatasi Perubahan Iklim (Studi Kasus: Coca-Cola Mengatasi Perubahan Iklim)
}

\author{
Hazazi Ridho Subarkah*1 \\ ${ }^{1}$ Pascasarjana Program Studi Ilmu Hubungan Internasional, Universitas Padjadajaran \\ Jl. Bukit Dago Utara No.25, Bandung, Indonesia \\ e-mail: *11 hazaziridho44@gmail.com
}

\begin{abstract}
This research focuses on the impact of climate change globally, the process of the meeting that took place in Paris in 2015 where the meeting was one of the efforts to tackle climate change. By using qualitative methods and concepts of environmental diplomacy, MNC concepts, and international regimes. The MNC concept is seen from Coca-Cola's efforts to tackle climate change. Through an analysis of the concept of environmental diplomacy, negotiation efforts were made at COP21 in Paris and resulted in the Paris Agreement. Paris Agreement as a reference to tackle climate change, bearing in mind that the international regime is as stringent as international rules, values and norms agreed by the countries that agree on it and can apply to international actors. Coca-Cola as an MNC in an effort to tackle climate change using its reference is the Paris Agreement, and Coca-Cola in this case is making various efforts in overcoming climate change, for example by conducting a revolution in business, so that eco-friendly economic relations will be built.
\end{abstract}

Keywords-Climate Change, Coca-Cola, Environmental Diplomacy

\begin{abstract}
Abstrak
Penelitian ini berfokus pada dampak yang ditimbulkan dari perubahan iklim secara global, proses dari pertemuan yang terjadi di Paris tahun 2015 yang mana pertemuan tersebut merupakan salah satu upaya untuk mengatasi perubahan iklim. Dengan menggunakan metode kualitatif dan konsep diplomasi lingkungan, konsep MNC, dan rezim internasional. Konsep MNC merupakan dapat dilihat dari upaya Coca-Cola dalam mengatasi perubahan iklim. Melalui analisis konsep diplomasi lingkungan, upaya negosiasi dilakukan dalam COP21 di Paris dan menghasilkan Paris Agreement. Paris Agreement sebagai acuan untuk mengatasi perubahan iklim, mengingat rezim internasional ialah seperangat aturan, nilai dan norma internasional yang disepakati oleh negara-negara yang menyepakatinya dan dapat berlaku bagi aktor internasional. Coca-cola sebagai MNC dalam upaya mengatasi perubahan iklim menggunakan acuannya ialah Paris Agreement, dan Coca-Cola dalam hal ini melakukan berbagai upaya dalam mengatasi perubahan iklim misalnya ialah melakukan revolusi terhadap bisnis, sehingga akan terbangun perkekonmian yang ramah lingkungan.
\end{abstract}

Kata kunci- Coca-Cola, Diplomasi Lingkungan, Perubahan Iklim 


\section{Pendahuluan}

Multinational Corporation (MNC) merupakan salah satu penyumbang emisi karbon akibat dari proses produksinya, hingga akhirnya menyebabkan perubahan iklim. Setelah era perang dunia II ruang pembahasan ilmu Hubungan Internasional menjadi semakin luas salah satunya ialah isu lingkungan. Isu lingkungan dimetaforakan menjadi tragedy of common, yakni krisi lingkungan yang terjadi di satu wilayah akan menyebabkan bencana di wilayah lainnya, hal ini penting untuk dibicarakan pada tingkat global (Robert Jackson \& Georg Dorensen, 2009, hal. 324).

Isu penting dari krisis lingkungan salah satunya ialah perubahan iklim. Perubahan iklim begitu terasa dampaknya ke berbagai negara, dampak yang ditimbulkan akibat berubahnya iklim tidak dapat diprediksi, sehingga mengancam kehidupan baik manusia, hewan dan tumbuhan bahkan dalam skala besar yaitu negara. Perbuhanan iklim disebabkan oleh negara yang melakukan industrialisasi di negaranya, karena proses industrialisasi tersebut memproduksi gas karbon dioksida (CO2). Adapun beberapa negara emitor ialah China, Amerika Serikat, Serikat Eropa, India, Rusia, Jepang, Jerman, Korea Selatan, Kanada, dan Indonesia (Parikesit, 2015

https://www.cnnindonesia.com/internasion al/20151130171044-137-94992/sepuluhnegara-penghasil-emisi-karbon-dioksidaterbesar diakses pada tanggal 25/09/2019).

Perubahan iklim disebabkan oleh aktivitas manusia dari sektor industri, disamping akibat dari aktivitas alamiah lingkungan sendiri, aktivitas manusia sangat berpengaruh terhadap perubahan iklim. Aktivitas manusia atas ekspolitasi alam dan aktivitas indutrialisasi yang terjadi menghasilkan gas rumah kaca, yang akhirnya terjadi perubahan alamiah lingkungan. Gas rumah kaca yang menumpuk di atmosfer menyebabkan suhu bumi meningkat dan tidak wajar, dampak lainya menyebabkan permukaan air laut meingkat disebabkan oleh mencairnya es yang berada di kutub Utara dan Selatan (https://lingkunganhidup.co/penyebabperubahan-iklim-pemanasan-global/ diakses tanggal 24/09/2019).

Penyebab dari perubahan iklim tidak lepas dari aktivitas manusia dengan proses indutrialisasi yang dilakuakn, Berdasarkan gambar 2.1 tersebut dapat dilihat penyumbang emisi karbon ialah dari proses industrialisasi sebanyak 65\%. Selanjutnya ialah aktivitass manusia lainya ekspolitasi sumber daya alam lingkungan yang berlebihan yakni deforestasi atau penggundulan hutan. Selebihnya ialah aktivitas lingkungan yang secara alamiah melakukan tugasnya masing-masing untuk menjaga kelangsungan keseimbangan lingkungan hidupnya. Berikut sektor yang merupakan emitor penyebab perubahan iklim.

\section{Gambar 1. Sektor Penyumbang Emisi Karbon}

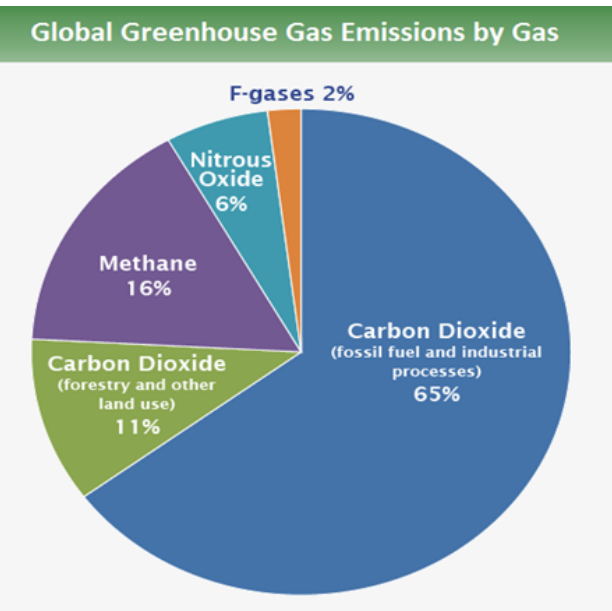

Source: IPPC 2014 
Gambar 1.1 ini menunjukan bahwa aktivitas dari industrialisasi menjadikan keseimbangan lingkungan hidup berubah, yang akhirnya meyebabkan perubahan iklim secara tidak wajar (https://www.epa.gov/sites/production/file s/2016-

05/global_emissions_gas_2015.png

diakses pada tanggal 28/02/217). Penting untuk menjadikan isu krisis lingkungan karena berdampak ke berbagai sektor baik ekonomi, politik, dan sosial budaya. Akibat dari proses industrialisasi tersebut posisi negara industri sangat penting. Karena dampak perubahan iklim tersebut berdampak pada ketersediaan pangan dunia, diakibatkan oleh kekeringan dan intensitas hujan yang berekpanjangan sehingga gagal panen. Kegagalan panen tersebut menyebabkan kelaparan (http://www.dw.com/id/perubahan-iklimpicu-kelaparan/av-18980926 diakses pada tanggal 02/11/2016 pkl 22:53 WIB).

Selain itu, dampak gas rumah kaca dapat dilihat saat kebakaran hutan di Indonesia yang mana disebabkan oleh fenomena iklim El Nino, fenomena ini memiliki durasi lebih panjang dari biasanya akbiatnya terjadi kebakaran hutan. Dampaknya asap dari hasil kebakaran hutan tersebut melanda ke negara tetangga yakni Malaysia, Singapura, dan Thailand. Pada permasalahan sosial terjadi di negar berkembang juga terkena dampaknya seperti pernikahan dini, pemicunya ialah perubahan iklim, karena tidak ingin menjadi beban keluarga, sang anak akhirnya dinikahkan untuk mengurangi beban keluaraga. Di belahan lainnya, terjadi fenomena kebalikan, yakni curah hujan makin tinggi dan dibelahan lain kekeringan terus terjadi. Banjir yang terjadi menjadikan jutaan orang bermingrasi. Di Afrika terjadi gagal panen di kawasan Afrika dan Asia Selatan. Selain itu juga timbul pula wabah penyakit akbat iklim yang tidak menentu

(https://www.dw.com/id/dampak-

perubahan-iklim-sudah-landa-dunia/g-

18873686 diakses pada tanggal

25/09/2019).

Upaya menangani krisis lingkungan yang terjadi pada tingkat global, Perserikatan Bangsa-Bangsa (PBB) melaksanakan kerjasama multilateral antar negara tahun 1992 yakni Konferensi tingkat Tinggi PBB di Rio de Jaenero, Brazil. Sering disebut KTT Bumi, konfernsi ini mebahas upaya mengatasi lingkungan dan bagaimana upaya keberlangsungan lingkungan hidup sebagai sebuah agenda global (Wibisono, 2015 : 85). Sebelumnya pada tahun 1972 di Stockholm dilaksanakan konferensi Lingkungan Hidup Dunia yang hasilnya ialah terbentuknya badan yang menangani permasalahan lingkungan hidup yaitu United Nations Enviromental Programme (UNEP). Konferensi ini menjadi pembicaraan pertama menganai permaslahan lingkungan (Rudy, 1993:169).

Pada tahun 2015 pertemuak ke 21 atau COP21 dilaksanakan di Paris dihadiri oleh 195 negara. Pertemuan tingkat global bahwa negosiasi negara-negara tersebut dalam upaya mengurangi emisi karbon dan gas rumah kaca, seperti diketahui merupakan penyebab dari perubahan iklim. Hasil kesepakatan tersebut dinamai Paris Agreement. negara-negara yang terlibat setidaknya menyepakati lima pokok kesepakatan, yaitu; Pertama, adanya mitigasi, dengan mengupayakan untuk menjaga suhu bumi dibawah 2 derajat celcius. Kedua, sistem pelaporan penghitungan emisi karbon secara transparan. Ketiga, adanya upaya adaptasi hasil perjanjian. Keempat, memperkuta upaya pemulihan bencana yang diakbiatkan dari bencana perubahan iklim. Kelima, bantuan, yakni memberikan pendanaan bagi negara yang gunanya untuk 
pembangunan yang berkelanjutan dan ekonomi hijau https://internasional.kompas.com/read/201 5/12/13/09090031/Beberapa.Kesepakatan. Konferensi.Perubahan.Iklim.Paris diakses pada tanggal 25/09/2019).Pertemuan tersebut menjadi tongak dimulainya menangani krisis lingkungan, dikarenakan pada tahun tersebut semua pihak yang ada ikut menandatangani hasil kesepakatan.

Untuk menangani perubahan iklim tersebut tidak hanya dari pihak negara, namun juga dari korporasi. Mengingat sektor industri sebagai penyumbang emisi kabron tersebut, maka Coca-Cola yang merupakan Multinational Corporation memiliki peran penting dalam menangani perubahan iklim. Coca-Cola merupakan emitor yang lebih tinggi dari beberapa minuman lainnya, bahwa $330 \mathrm{ml}$ CocaCola yang dijual di Inggris memiliki jejak karbon $170 \mathrm{~g}$, sementara kaleng Coke Zero atau Coke Zero berukuran sama memiliki jejak 150 g. Botol kaca Coca-Cola 330-L memiliki jejak 360 g. Penelitian menytakan serangkaian aktivitas produksi yang dilakukan oleh korporasi dalam hal ini Coca-Cola bahwa dalam hal kemasan menyumbang bagian terbesar dari jejak karbon minuman, antara $30 \%$ dan $70 \%$, tergantung pada jenis wadah yang digunakan. Coca-Cola produksinya baik bahan-bahannya, kemasan, pendistribusian, penyimpanan, dan penggunaan serta pembuangan oleh konsumen merupakan penyumbang emisi karbon

https://www.greenerpackage.com/metrics standards/coke $\% \mathrm{E} 2 \% 80 \% 99$ s_carbon foot prints_are_revealed diakses pada tanggal 25/09/2019).

Melihat dampak dari krisis lingkungan global ini, dalam konsep thinking green menyatakan upaya untuk menangani perubahan iklim atau krisis lingkungan dapat ditangani melalui forum maupun institusi global (Steans, Jill \& Lloyd Pettiford, 2009; 380). Perubahan iklim diperlukan adanya kerjasama semua elemen aktor hubungan internasional, yaitu negara, IGO, NGO, MNC, Individu dan aktor-aktor lainnya dalam upaya menganani krisis lingkungan. Pada pertemuan COP21, Coca-Cola ikut andil dalam pertemuan tersebut. Coca-Cola memiliki komitmen untuk menangani perubahan iklim. Untuk mengatasi permasalahan ini, perlu kerja sama dilakukan oleh aktor-aktor lain selain negara.

Berdasarkan uraian yang dikemukakan sebelumnya dampak dari perubahan iklim ke berbagai sektor, dan diharuskan adanya peran dari berbagai aspek baik aktor negara maupun non-negara dalam hal ini korporasi Coa-Cola, maka peneliti tertarik untuk melakukan penelitian dengan judul: Upaya Multinational Corporation (MNC) Dalam Mengatasi Perubahan Iklim dengan Studi Kasus : Coca Cola dalam Paris Agreement 2015.

\section{Kajian Pustaka dan Kerangka Pemikiran}

\subsection{Diplomasi Lingkungan}

Diplomasi merupakan salah satu upaya untuk mengatasi satu permasalahan global. Brian White dalam Baylis, J dan Steve Smith menyatakan diplomasi adalah sebuah instumen yang ditawarkan, dimana aktor internasional menggunakan untuk menerapkan politik luar negerinya. Definisi ini tidak hanya mnggambarkan bahwa hanya negara saja tapi aktor internasional yang bukan non negara (Prambudianto, 2011, hal. 17). Sementara Magalh es membatasi istilah diplomasi pada kegiatan- 
kegiatan diplomat profesional, melalui perantara-perantara yang disetujui oleh masing-masing pihak (Walter Carlsnaes, Thomas Risse, dan Beth A Simmons, 2013).

Hakikatnya diplomasi merupakan kegiatan komunikasi diantara para diplomat profesional yang mewakili negaranya masing-masing, dimana pada umumnya kegiatan itu dilakukan untuk memperjuangkan kepentingan nasional negaranya masing-masing. Diplomasi dapat berupa membahas isu-isu penciptaan perdamaian, perdagangan, perang, ekonomi, budaya, lingkungan, dan HAM. Perjanjian-perjanjian internasional biasanya juga dinegosiasikan oleh para diplomat sebelum disahkan dalam forum lebih tinggi (misalnya KTT atau pertemuan tingkat menteri) (Bakry, 2017, hal. 159).

Borg dalam mendefinisikan diplomasi lingkungan yang dibuat cukup sederhana yaitu : "Enviromental diplomacy can be defined as the skill in handling enviromental issues, whose implications are international in scope" atau terjemahan bebasnya "Diplomasi lingkungan dapat didefinisikan sebagai keahlian dalam menangani persoalan-persoalan lingkungan hidup yang memiliki dampak dalam lingkup internasional." (Bakry, 2017, hal. 26).

Berdasarkan definisi yang dikemukakan diatas, penulis sendiri memberanikan diri untuk menyimpulkan bahwa diplomasi lingkungan merupakan upaya aktor-aktor hubungan internasional untuk menjaga lingkungan, agar mereka dapat hidup dengan nyaman dan aman melalui konferensi-konferensi untuk kebutuhan bersama. Selanjutnya, aktor yang berada dalam sebuah negosiasi tersebut harus memiliki keterampilan dan keahlian seperti yang penulis kutip diatas.

$$
\text { Melalui konsep Diplomasi }
$$

Lingkungan Brog ini bahwa isu perubahan iklim menjadi penting bagi MNC dan juga negara-negara di dunia untuk menjaga suhu bumi atau secara umum menjaga lingkungan. Penggunaan konsep diplomasi lingkungan yang dikemukakan oleh Borg melalui COP21 adalah instrumen untuk negara-negara mendiskusikan dan kerjasama dalam upaya menjaga lingkungan, dalam hal ini jadilah sebuah kesepakatan yang dikenal Paris Agreement. COP21 tidak hanya diperuntukan bagi negara saja namun aktor lain yaitu $\mathrm{MNC}$ juga terlibat dalam upaya menangani isu perubahan iklim. Diplomasi lingkungan ini menjadi sebuah agenda bersama yang mana tidak hanya satu negara yang memiliki tanggung jawab, negara lain juga perlu mempertanggung jawabkannya. Aktor Perusahan Multinasional corporation juga andil dalam mempertanggung jawabkan dampak yang ditimbulkan dari perubahan iklim. Coca-Cola sebagai aktor MNC memiliki tanggung jawab dalam mengatasi perubahan iklim dengan ikut serta melakukan upaya-upaya dengan produk ramah lingkungan dan menjadi investor dalam pembangunan berkelanjutan.

Diplomasi lingkungan membuahkan hasil sebagai sebuah rezim internasional yang akan digunakan oleh para pihak untuk acuan dalam mengatasi perubahan iklim. Rezim internasional yang dikemukanan oleh Krasener (1977) berpendapat rezim merupakan seperangkat prinsip-prinsip, 
norma, aturan, dan prosedur pengambilan keputusan (Krasener dalam Florini,1996;34). Pada pertemuan di Paris tahun 2015 tersebut menghasilkan sebuha rezim lingkungan atau dikenal dengan Paris Agreement yang disetujui oleh 195 negara (

http://www.antaranews.com/berita/534820 /195-negara-setujui-kesepakatan-paris diakses pada tanggal 19/04/2019). Setidaknya ada lima pokok hasil dari kesepakatan tersebut dan dijadikan acuan dalam upaya mengatasi perubahan iklim, yakni Pertama, adanya mitigasi, dengan mengupayakan untuk menjaga suhu bumi dibawah 2 derajat celcius. Kedua, sistem pelaporan penghitungan emisi karbon secara transparan. Ketiga, adanya upaya adaptasi hasil perjanjian. Keempat, memperkuta upaya pemulihan bencana yang diakbiatkan dari bencana perubahan iklim. Kelima, bantuan, yakni memberikan pendanaan bagi negara yang gunanya untuk pembangunan yang berkelanjutan dan ekonomi hijau https://internasional.kompas.com/read/201 5/12/13/09090031/Beberapa.Kesepakatan. Konferensi.Perubahan.Iklim.Paris diakses pada tanggal 25/09/2019).

\subsection{Multinational Corporations (MNC)}

Dalam kajian ilmu Hubungan Internasional memiliki aktor untuk dianalisis yakni aktor negara dan non negara, dalam hal ini aktor non negara yaitu Multinational Corporations merupakan aktor dalam Hubungan Internasional yang mana memiliki peran penting dalam politik global (Perwita, dan Yanyan M. Yani,
2017:11). MNC adalah sebuah perusahaan yang berusaha diberbagai negara tetapi dikelola dari satu negara (home country). Perusahaan biasanya memiliki kantor pusat dimana mereka dapat mengorperasikan dan mengkoordinasikan manajemen global. MNC mengglobalisasikan kegiatannya dengan tujuan baik memasok pasar dalam negeri mereka, maupun untuk melayani pasar luar negeri secara langsung. Sebuah MNC yang sangat besar memiliki budget yang lebih besar dari APBN negara-negara kecil (Bakry, 2017:201).

Robert Gilpin secara sederhana mendefinisikan MNC merupakan sebuah perusahaan besar memiliki dan memngelola unit-unit ekonomi lebih dari satu negara. MNC cenderung merupakan sebuah perusahaan oligopolistik dimana kepemilikan, pengelolaan, produksi, dan aktivitas penjualannya berkembang hingga melintasi batas negara. Sebuah MNC biasanya terdiri dari kantor pusat di satu negara dengan sekelompok anak perusahaan di berbagai negara. Tujuan prinsip korporasi adalah untuk mengamankan biaya produksi barang paling rendah untuk keperluan pasar dunia. Tujuan ini dapat dicapai dengan mencari lokassi yang paling efisien untuk pasilitas produksi atau memperoleh konsesi pajak pemerintah negara setempat (Gilpin dalam Bakry, 2017:202).

MNC sebagai aktor dalam bisnis internasinoal. Perusahaan sangat memiliki peran penting dalam konstelasi internasoinal. MNC bisa memainkan peranan dalam kebijakn-kebijakan yang dikeluarkan oleh negara baik pada tingkat nasional maupun global. Karena potensi ekonomi yang dimiliki oleh MNC, memiliki pengaruh dalam perpolitikan domestik maupun global. MNC juga menjadi salah satu yang menyebabkan perubahan iklim dunia, maka dari itu perlu adanya komitmen dari MNC untuk 
menjaga lingkungan dengan melakukan pembangunan yang berkelanjutan.

Perusahaan-Perusahaan Multinasional memiliki peran penting dalam latar belakang terlaksananya COP21 di Paris. Karena perusahaan multinasional memiliki pendapatan lebih banyak dari aktor negara dalam hal ini APBN negara, maka kekayaan yang dimiliki perlu digunakan untuk melakukan pembangunan yang berkelanjutan. Dampak yang ditimbulkan dari proses prosduksi industrilaisasi perusahaan Multinasional diperlukan dalam melakukan investasi pembangunan berkelanjutan untuk upaya menangani perubahan iklim. Investasi tersebut akan bermanfaat untuk organisasi- organiasi internasional dalam efisiensi energi hingga akhirnya pehematan biaya (https://www.irishtimes.com/opinion/multi national-corporations-important-playersin-the-background-of-cop21-1.2450573 pada tanggal 26/09/2019).

Coca-Cola sebagai perusahaan multinasional memiliki upaya untuk melakukan pembangunan berkelanjutan. Coca-cola dalam menganai isu lingkungan telah melakukan upaya tersebut. General Mills dan Kellogg's melihat dampak yang ditimbulkan akibat perubahan iklim memiliki pengaruh dalam bisnisnya. Setidaknya ada 3 yang utama mengapa perusahan-perusahaan untuk mengatasi perubahan iklim, yaitu pertama perubahan iklim dan biaya ekonominya. Perubahan iklim tidak baik bagi bisnis. Banjir dan kekeringan yang tidak dapat terprediksi akan membuat bisnis merugi, sehingga perlu adanya upaya untuk membuat suhu bumi semakin baik. Kedua, ketersediaan sumberdaya bagi perusahaan. Kendala sumber daya merupakan salah satu penyebab perusahaan merugi. Saat perubahan iklim terjadi, banyak tanaman yang tidak mampu berkembang akibat tidak ramahnya cuaca saat terjadi perubahan iklim. Ketersediaan air misalnya saat kekeringan sangat mempengaruhi perusaan minuman ini seperti Coca-cola. Ketiga, adanya transaparansi dalam perusahaan dan produk mereka. Adanya transparansi yang digerakan dengan teknologi dilakukan oleh perusahaan untuk memantau pelanggan, komunitas, karyawan dan pemangku kepentingan yang peduli akan perubahan iklim. Para aktor ini ingin mengetahui dari mana berasal makanan dan minuman yang dia konsumsi hingga sampai kepada konsumen (https://www.cocacolacompany.com/stories/Why-the-

Business-World-is-Tackling-ClimateChange diakses pada tanggal 25/09/2019) \

Perusahaan Multinasional pada dasarnya memiliki peranan penting dalam mengatasi perubahan iklim, selain sebagai penyebab ia juga memiliki peran dalam mengatasinya dengan segala kemampuan yang ia miliki terutama dalam biaya pembangunan keberlanjutan. Perubahan iklim dan perusahaan memiliki keterkaitan. Apabila iklim lingkungan baik, maka perusahaan pun akan baik, dapat dilihat apabila ketersediaan sumberdaya yang menjadi bahan pokok perusahaan dapat mempengaruhi perusahaan tersebut, seperti contoh Coca-Cola yang memerlukan air untuk keberlanjutan bisnisnya, apabila terjadi kekeringan, maka perusahaan tersebut akan merugi, dan apabila banjir pun akan mempengaruhi perusahaan tersebut, dengan air yang tersedia. Pada pertemuan di Paris 2015 yang menghasilkan Paris Agreement, Coca-cola ikut serta dan memiliki peran penting dalam menangani perubahan iklim.

\section{Metode Penelitian}

Penelitian ini menggunakan metode kualitatif yang bertujuan untuk mengetahui 
proses diplomasi dalam upaya menangani krisis lingkungan. Selain itu upaya yang dilakukan oleh MNC dalam mengatasi perubahan iklim. Untuk menganalisis penelitian ini menggunakan konsep MNC, Diplomasi Lingkungan, dan rezim internasional. sedang, teknik pengumpulan dalam penelitian ini menggunakan studi pustaka atau mengumpulkan data dari sumber-sumber yang relevan dan terpercaya.

\section{Hasil dan Pembahasan}

\subsection{Perubahan Iklim sebagai Masalah Global}

Perubahan iklim sebagai masalah global diakibatkan oleh aktivitas manusia. Perubahan iklim sendiri ialah adanya perubahan komposisi atmosfer secara global dan perubahan variabilitas iklim yang teramati pada kurun waktu yang tidak dapat dibandingkan, secara sederhada iklim yang tidak dapat diprediksi (DPR RI, 2009, www.dpr.go.id/dokjdih/document/uu/UU 2009_31.pdf diakses pada tanggāl 27/09/2019).

Perubahan iklim terjadi akibat penggunanan energi tak terbarui seperti batu bara, yang mana hasil pembakaran tersebut menggandung karbon dioksida secara berlebihan dan enegeri tersebut melepaskan gas rumah kaca yang akibatnya peningkatan suhu bumi, hingga akibatnya terjadi peubahan iklim (Winarno, 2014:153). Perubahan iklim dapat memiliki dampak ke berbagai sektor, adapun dampak perubahan iklim dapat dilihat pada gambar berikut.

\section{Gambar 2. Dampak Perubahan Iklim Bagi Dunia}

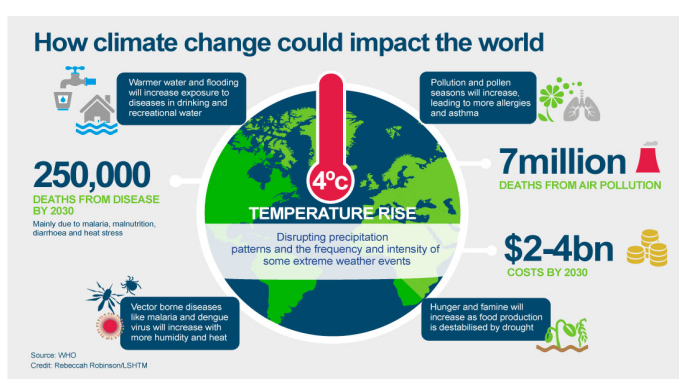

Source: WHO 2016

Berdasarkan gambar tersebut dapat dilihat bawa meningkatnya suhu bumi akan memiliki dampak yang ditimbulkan akibatnya terjadi perubahan iklim. Dampaknya terjadi ke berbagai sektor, mulai dari kekeringan dan banjir yang menyebabkan gagal panen maupun bencana lainnya. Polusi yang dapat mengaggu pernafasan, wabah penyakit hingga menurunnya ketersediaan pangan dunia

(https://www.1shtm.ac.uk/research/researc h-action/features/how-climate-changeaffecting-your-health diakses pada tanggal 27/10/2019).

Dampak perubahan iklim salah satunya disebabkan oleh aktivitas perindustrian. Akibat dari industrialisasi memilki dampak peningkatan suhu bumi dapat melehnya es yang berada di Antartika. Jurnal Nature memperediksi melelehnya lapisan es yang berada di Antartika meyebabkan meingkatnya dua kali lipat volume air laut hingga 2 meter, apabila upaya kurangi emisi karbon dioksida tidak dapat ditangani (https://www.liputan6.com/global/read/24 72099/ilmuwan-kenaikan-permukaan-airlaut-akan-semakin-cepat diakses pada tanggal 27/09/2019). Kenaikan volume air laut ini berdampak pada negara-negara kepulauan yang akan menyebabkan negara tersebut akan tenggelam daerah-daerah 
Indo-China, Indus di Pakistan. Afrika bagian Timur, India dan Indonesia dan negara keupaluan lainnya (Foley, 1993:49).

Perubahan iklim yang terjadi juga terkena dampak ke Filipina, India, dan Kamboja. Ketiga negara tersebut mengalami bencana angin topan Haiyan tahun 2012 berakibat korban jiwa 6.300 orang, kerugian secara finansial sebanyak US\$ $13 \quad$ Miliar (https://www.cnnindonesia.com/internasio nal/20141203012548-134-15419/negaraberkembang-terkena-dampak-palingparah-perubahan-iklim diakses pada tanggal 27/09/2019). Perubahan iklim ekstrim di India sendiri tahun 2012 mengalami bencana globang panas yang menyebabkan kekeringan, globang panas yang akibatnya tingginya suhu ekstrim hingga menyebabkan korban jiwa sebesar 1.826 jiwa (https://m.tempo.co/read/news/2016/04/22/ 118764955/gelombang-panas-di-india-1826-orang-tewas diakses pada tanggal 27/09/2019). Di belahan bumi lain perubahan iklim terjadi di Alaska, Obama Presiden Amerika Serikat mengatakan badai ekstrim terjadi di Alaska, lebih sering dari biasanya terjadi kebakaran hutan. Selain itu juga terjadi hingga kondisi glester memburuk dan erosi terjadi di pantai di dunia (http://nationalgeographic.grid.id/read/133 01276/alaska-negara-yang-terkenadampak-perubahan-iklimterparah?page $=$ all diakses pada tanggal 27/09/2019).

Aspek lain yang terkena dampak dari perubahan iklim ialah pada aspek ketahan pangan dunia. Ancaman ketersedian pangan dunia menurut Asia Development Bank (ADB) disebabkan oleh perubahan iklim yang terjadi. Mengancam ketahanan pangan diakibatkan efek kekeringan dan banjir di kawasan Pasifik yang merupakan negara agraris sekaligus maritim. Daerah kawasan pantai rentan akan berkurangnya hasil tangkapan laut (https://finance.detik.com/berita-ekonomibisnis/d-1721264/adb-waspadai-ancamankemarau-di-asia-pasifik diakses pada tanggal 27/09/2019). Ancaman ketersediaan pangan tersebut mengancam negara-negara Sub-Sahara Afrika karena ketersediaan pangan akibatnya kelaparan dan kemiskinan terus terjadi (http://geotimes.co.id/perubahan-iklimdan-dunia-yang-terancam-kelaparankemiskinan/\#gs.PiGhHA4 diakses padda tanggal 27/09/2019).

Pada aspek sosial kegagalan panen para petani menyebabkan kehilangan mata pencaharian dan kerugian biaya produksi. Kegagalan panen tersebut dikarenakan fenomena el nino yang berkepanjangan. Gagal panen tersebut berdampak pada kurangnya asupan gizi dan kelaparan. Fenomena El nino ini melanda 17 Negara mengalami kekeringan selama dua tahun berturut-turut tahun 2015 hingga 2016 memakan korban jiwa sebanyak 38 jiwa. Negara-negara tersebut diantaranya sebagai berikut; Angola 1,2 juta korban jiwa, Djibouti 227.463 korban jiwa,Burundi 3 juta jiwa. Eritera 450 ribu jiwa, Etiopia 5,7 Juta jiwa, Kenya 2.6 juta jiwa, Lesotho 159959 jiwa, Madagaskar 978 ribu jiwa, Malawi 6.7 juta jiwa, Mozambik 2 juta jiwa, Rwanda tidak diketahui, Somalia 6.3 juta jiwa, Sudan 4.6 juta jiwa, Swaziland 638 ribu jiwa, Tanzania tidak diketahui, Uganda 390 ribu jiwa, Zimbabwe 4.1 juta jiwa

(http://www.irinnews.org/feature/2017/03/ 17/drought-africa-2017 diakses pada tanggal 27/09/2019).

Dampak lainya ialah imigrasi besarbesaran terjadi. Para migram lebih dari 10 ribu jiwa yang melakukan perjalanan melalui Hongaria menuju ke Eropa Barat. Migrasi juga terjadi dari Suriah ke Eropa Barat yang mana salah satu penyebabnya 
ialah perubahan iklim. Para ilmuan menganggap salah satu tambahan faktor penyebab imigrasi terjadi dikarenakan perubahan iklim. Pada Procedings of the National Acaddemy of Sciences of United State of America menyebutkan imigrasi tahun 2006 dan 2011 diakibatkan dari ekstrimnya kekeringan di daerah Suriah. Ilmuan Franesco Femia, Center for Climate and Security, Wasington DC menyebutkan "That drought, in addition to its mismanagement by the Assad regime, contributed to the displacement of two million in Syiria". Ia menyatakan migrasi yang terjadi adalah dampak dari kekeringan sebagai salah satu faktor disamping kesalahan dari rezim Assad (https://time.com/4024210/climatechange-migrants/ diakses pada tanggal 28/09/2019).

Perubahan iklim sebagai permasalahan global karena membawa dampak terhadap negara-negara yang ada di dunia. Ancaman yang terjadi disatu wilayah memiliki dampak ke wilayah lain dikarenakan efek dari perubahan iklim, baik ke aspek sosial maupun aspek lainnya. Apabila tidak ada kesadaran dari satu negara akan membawa dampak juga terhadap lingkungan negara lain dan membawa permasalahan, seperti yang diuraikan sebelumnya.

\subsection{Diplomasi Lingkungan di Conference of Parties (COP) ke $21 \mathrm{di}$ Paris 2015}

Krisis lingkungan dalam perubahan iklim diperlukan kerjasama global, salah satu caranya ialah melalui diplomasi pada tingkat forum-forum internasional. Berdasarkan diplomasi yang dikemukakan oleh Borg mengenai diplomasi lingkungan ia menyatakan bahwa upaya untuk menangani persoalan-persoalan lingkungan hidup melalui kerjasama negara-negara di dunia yang akhirnya menghasilkan sebuah acuan untuk mengangani perubahan iklim.

Melalui conference of parties (COP) ke 21 sebagai instrumen untuk negara-negara melakukan diskusi dan kerjasama dalam uapaya menangani krisis lingkungan dalam hal ini perubahan iklim. COP21 ialah pertemuan ke 21 yang dilaksanakan di Paris pada tahun 2015. COP merupakan badan tertinggi saat ingin membuat kebijakan pada badan perubahan iklim PBB yakni United Nation Framework Convention on Climate Change (UNFCCC). Tujuan dari COP itu ialah meninjau pelaksanaan konvensi yang sudah pernah dilakukan. Pertemuan ini dihadiri dari 36 ribu peserta, hampir 23.100 pejabat pemerintah, 9.400 perwakilan dari badan-badan PBB, lembaga organisasi antar pemerintah,organisasi masyrakat sipil, dan 3.700 awak media (Summary of the Paris Climate Change Conference, 2015).

Pada pertemuan ke 21 di Paris untuk pertama kalinya menuai kesepakatan dari para peserta anggota konferensi untuk meratifikasi hasil dari COP21. Hasil tersebut mengikat secara hukum dan universal dengan tujuan menjaga pemanasan global dibawah 2 derajat celsius. Sesuai dengan Paris Agreement dalam pasal 2 : "Holding the increase in the global average temperature to well below $2^{\circ} \mathrm{C}$ above pre-industrial levels and pursuing efforts to limit the temperature increase to $1.5^{\circ} \mathrm{C}$ above pre-industrial levels, recognizing that this would significantly reduce the risks and impacts of climate change." Pada pasal kedua ini secara sederhanya upaya mengurngi suhu bumi 1.5 derjat Celsius dan berupaya untuk dibawah 2 derajat celsius sebagai upaya untuk mengatasi dampak dari perubahan iklim

(https://unfccc.int/files/essential_backgrou $\mathrm{nd} /$ convention/application/pdf/english_pari s_agreement.pdf diakses pada 28/09/2019). 
Tidak hanya aktor negara saja yang ikut serta, para pelaku bisnis juga mengambil pernanan dalam pertemuan di Paris tersebut. para pelaku bisnis mengumumkan diri untuk memberikan investasinya serta merubah regulasinya untuk upaya mengatasi perubahan iklim. Diantaranya BMW Group, Coca-Cola Enterprises, International Flavours \& Fragrances Inc., Nordea Bank AB, Pearson dan Swiss Post telah mengumumkan mereka akan menggunakan 100 persen listrik mereka dari energi terbarukan, mengambil jumlah total berkomitmen perusahaan untuk 53. Perusahaan besar lainnya termasuk Microsoft, Adobe dan Google

(https://www.environmentalleader.com/20 15/12/cop21-roundup-schneider-electricacciona-bmw-coca-cola-unilever-elonmusk/ diakses pada tanggal 28/09/2019).

Perusahaan-perusahaan mengakui pembangunan keberlanjutan dapat merugikan perusahaan, namun fakta hal tersebut dibutuhkan oleh pasar, Mengingat dampak yang ditimbulkan dari perubahan iklim. Kevin Moss, Direktur Global WRI Businness Center mengakui bahwa perubahan iklim mengganggu rantai pasokan, pasar dan operasi mereka. Regulasi untuk melakukan pembangunan berkelanjutan mempengaruhi operasional perusahaan. Ceres sebagai Business for Innovative Climate and Energy Policy, or BICEP mengajukan hal tersebut untuk dibahas. Berbagai perusahan multinasional berupaya untuk mengatasi perubahan iklim dengan menandatangani perjanjian perubahan iklim. Lebih dari 1.000 perusahaan menandatangani "coordinated effort to combat climate change". Misalnya Apple, Intel, GM, Nike, Uniliver dan banyak lagi termasuk Coca-Cola.

Perusahaan tersebut berupaya untuk memberi perhatian pada upaya penanganan perubahan iklim. Sejauh ini dapat dilihat bahwa komitmen tersebut dilakukan oleh merek besar Eropa seperti IKEA, BT Group, Commerzbank, H \& M, Unilever dan Marks \& Spencer, dan masing-masing telah berkomitmen untuk mendapatkan 100 persen listrik mereka dari sumber terbarukan

(https://www.worldfinance.com/specialreports/the-relationship-between-

corporations-and-climate-change diakses pada tanggal 28/09/2019).

Proses diplomasi yang dilakukan para aktor di Paris tersebut sebagai arena dalam mengatasi perubahan iklim pada akhirnya tercapai kesepakatan, setidaknya lima point kesepaktan tersebut Pertama, adanya mitigasi, dengan mengupayakan untuk menjaga suhu bumi dibawah 2 derajat celcius. Kedua, sistem pelaporan penghitungan emisi karbon secara transparan. Ketiga, adanya upaya adaptasi hasil perjanjian. Keempat, memperkuta upaya pemulihan bencana yang diakbiatkan dari bencana perubahan iklim. Kelima, bantuan, yakni memberikan pendanaan bagi negara yang gunanya untuk pembangunan yang berkelanjutan dan ekonomi hijau

https://internasional.kompas.com/read/201 5/12/13/09090031/Beberapa.Kesepakatan. Konferensi.Perubahan.Iklim.Paris diakses pada tanggal 25/09/2019). Hasil kesepakatan yang terjadi setelah melakukan diplomasi dikenal dengan Paris Agreement. sesuai hasil perjanjian internasional di Paris tahun 2015 dapat didefinisikan sebagai rezim internasional, dalam hal ini rezim lingkungan. Pada pertemuan ke 21 atau Conference of Parties (COP) ke 21 dihadiri oleh 195 negara pada akhir tahun 2015 di Paris, yang mana pada para negara-negara tersebut bersepakat dan menyetujui hasil dari isi Paris Agreement upaya untuk menangani mitigasi perubahan iklim

(http://www.antaranews.com/berita/53482 
0/195-negara-setujui-kesepakatan-paris diakses pada tanggal 28/09/2019)

Coca-cola Enterprise (CCE) menindak lanjuti kesepaktan Paris tersebut tidak hanya sebatas menandatangani saja. CCE menjadi tuan rumah dalam pertemuan para pemimpin perusahaan Corporate Leader Gourp (CLG), yang tujuannya untuk menyatukan para pebisnis, akademisi, think tank dan pembuat kebijakan di Paris membahas peran pemerintah, bisnis dan masyarakat sipil dalam memberikan transisi ke ekonomi rendah karbon. Pada akhirnya hasil kesepakatan COP21 akan menjadi aspek konsolidasi global yang diperlukan untuk mitigasi perubahan iklim (https://www.coca-

colacompany.com/stories/cop21-thinkingabout-how-will-we-collaborate-after-paris diakses pada tanggal 28/09/2019).

Kesepakatan mengenai Reducing Emissions from Deforestation and Forest Degradation (REDD) diabadikan dalam perjanjian Paris tersebut. Pada 15 Desember 2015 terjadi diskusi mengenai upaya mengurangi emisi karbon dengan tidak menebang pohon. Hal itu tercantum dalam pasal 5 perjanjian Paris yang hanya dua paragraf. Namun, paragraf tersebut komperhensif dalam mengurangi emisi karbon. Berikut kutipan pasal 5 yang berkaitan dengan REDD+, yaitu: "Parties should take action to conserve and enhance, as appropriate, sinks and reservoirs of greenhouse gases as referred to in Article 4, paragraph 1(d), of the Convention, including forests. Parties are encouraged to take action to implement and support, including through results-based payments, the existing framework as set out in related guidance and decisions already agreed under the Convention for: policy approaches and positive incentives for activities relating to reducing emissions from deforestation and forest degradation, and the role of conservation, sustainable management of forests and enhancement of forest carbon stocks in developing countries; and alternative policy approaches, such as joint mitigation and adaptation approaches for the integral and sustainable management of forests, while reaffirming the importance of incentivizing, as appropriate, non-carbon benefits associated with such approaches."

Pada pasal 5 tersebut mencantumkan tentang tanggung jawab semua negara dalam memelihara hutan agara bisa mengurangi emisi karbon. Tanggung jawab tersebut diberlakukan sesuai dengan emisi karbon yang dihasilkan oleh setiap negara. selain itu juga untuk menjaga ekosistem lingkungan, setiap negara harus melestarikan lingkungan melalui konservasi dan melakukan pembangunan yang berkelanjutan (http://www.ecosystemmarketplace.com/ar ticles/redd-in-the-paris-climate-accord-asummary/ diakses pada tanggal 28/09/2019).

Sesuai dengan konsep dari diplomasi lingkungan, bahwasanya pertemuan dan diskusi permasalahan perubahan iklim yang dilakukan di Paris merupakan salah satu bentuk diplomasi lingkungan. Ada permasalahan lingkungan yang dibahas sehingga terjadi komunikasi antar pihakpihak untuk mendapatkan solusi bersama dalam penanganan permasalahan lingkungan. Sehingga terjadi perjanjian internasional yang mana sebagai acuan untuk dilakukan aktor Hubungan Internasional dalam mengatasi perubahan iklim.

\subsection{MNC Coca-Cola dalam Upaya Menangani Perubahan Iklim}

Paris Agreement sebagai sebuah rezim internasional menjadi landasan perusahaan multinasional dalam menangani perubahan iiklim. Perubahan iklim merupakan 
permasalahan global yang memiliki dapak yang luas ke berbagai aspek dan diperlukan penangan secara bersama baik negara maupun non negara yakni termasuk bagi perusahaan multinasional. Melalui COP21 yang melahirkan Paris Agreement. CocaCola sebagai perusahaan multinasional menjadi salahh satu sponsor dalam pelaksanaan pertemuan perubahan iklim yang terjadi di Paris pada tahun 2015. Coca-Cola dengan hal tersebut berkomitmen untuk menanangi perubahn iklim

(http://www.cop21 paris.org/sponsors-andpartners/sponsors diakses pada tanggal 28/09/2019).

Peningkatan komitmen oleh sektor bisnis dalam pembangunan keberlanjutan telah memberikan kontribusi dalam mengatasi perubahan iklim. Merubah penanganan isu yang dari top-down kepada bottom-up. Ada 3 kunci utama dalam memberikan pandangan bahwa perubahan iklim sebagai sebuah peluang bagi para pebisnis, pertama, dapat menggunakan teknologi terbarukan yang mampu digunakan dan diberikan bantuan dari pihak negara maju. Yang mana dengan teknologi baru tersebut dapat menghemat biaya produksi. Kedua, penggunaan energi terbarukan tidak boros energi dan dapat mudah melakukan investasi. Ketiga, dengan menyederhanakan bahasa yang ada dalam paris agreement kepada para pebisnis agar mudah untuk dipahami (https://www.cokecce.com/news-andevents/news/cop21-an-unmissableopportunity-in-the-fight-against-climatechange diakses pada tanggal 28/09/2019).

Peran aktor non negara yakni CocaCola sebagai perusahaan multinasional melakukan upaya tersebut dalam mengani perubahan iklim. Adapun Coca-Cola membuat program daur ulang dalam produk yang dikeluarkannya misalnya dalam kemasan Coca-Cola Enterprise
(CCE) di Inggris. Kemasan kaleng aluminium Coca-Cola mengandung sekitar $50 \%$ konten daur ulang, dan botol kacanya mengandung rata-rata $40 \%$ kaca daur ulang. CCE juga telah menetapkan target untuk semua botol PET-nya di Inggris dan Eropa untuk menampung rata-rata 25\% PET daur ulang pada akhir 2010. Proses daur ulang yang dilakukan ini memiliki pengaruh dalam mengurangi emisi karbon seorang konsumen mendaur ulang kaleng Coke, dengan jejak karbon $170 \mathrm{~g}$, ini akan mengurangi jejak hingga $70 \mathrm{~g}$, membuatnya turun menjadi 100 g. Jika konsumen mendaur ulang sekaleng Diet Coke atau Coke Zero, ini akan mengurangi jejak karbon dari $150 \mathrm{~g}$ menjadi $85 \mathrm{~g}$ (https://www.greenerpackage.com/metrics _standards/coke $\% \mathrm{E} 2 \% 80 \% 99$ s_carbon_fo otprints_are_revealed diakses pada tanggal 26/09/2019)

CCE dalam upaya untuk mengurangi libah bahan baku botol plastik melakukan kerjasama dengan Artenius PET Packaging Eurpe (APPE). CCE telah menciptakan Infineo yaitu rumah daur ulang untuk libah botol plastik. Dengan menginvestasikan $€$ 8,7 juta di Infinéo, Coca-ColaEntreprise telah membiayai perluasan tempat pembuangan limbah Plastipak Packaging di Sainte-Marie-la-Blanche, Côte-d'Or. Kapasitasnya telah meningkat sebesar $70 \%$, berkat pemasangan jalur daur ulang baru. Pabrik ini sekarang mampu menghasilkan 48.000 ton per tahun PET daur ulang melalui jalur produksi baru, canggih. Penciptaan Infinéo melengkapi tindakan yang sudah dilaksanakan untuk mendukung lingkungan di Coca-Cola Entreprise, yang tujuannya, pada 2020, adalah mengurangi jejak karbonnya hingga sepertiga (https://www.coca-colafrance.fr/stories/Coca-Cola-et-1-economiecirculaire diakses pada tanggal 27/09/2019). 
Upaya lain yang dilakukan oleh CocaCola ialah dengan melakukan management air. Air yang merupakan sumber utama dari produksinya merupakan kerentanan saat perubahan iklim terjadi, maka dari itu ia mengelola air yang ada dengan bekerjasama World Wildlife Fund (WWF). Kesadaran dari perusahaan multinasional bahwa sumber daya alam air yang ia gunakan tersebut didaur ulang kembali untuk dipergunakan oleh masyarakat. Melalui kemitraan dengan WWF, Coke membantu melestarikan tujuh cekungan sungai di seluruh dunia yang sedang tertekan, termasuk deltas Sungai Yangtze dan Mekong, serta sungai dan sungai di bagian tenggara Amerika Serikat. Pentingnya penanganan air diberbagai sungai yang ada akan mempengaruhi produksi pasokan air tawar perusahaan (https://www.mnn.com/money/sustainable -business-practices/stories/coca-cola-andthe-environment diakses pada tanggal 29/09/2019).

Coca-cola hingga akhirnya pada tahun 2007 Coca-Cola mengumumkan tujuannya untuk mengisi kembali air yang digunakan hingga nanti pada tahun 2020. Program tersebut dilakukan dengan melalui 248 kemitraan air masyrakat di 71 negara di seluruh dunia mencapai tujuannya dalam pengelolaan air. The Nature Conservancy menemukan bahwa pada tahun 2015, CocaCola kembali 191.9 juta liter air ke alam atau komunitas manusia - 15\% dari air yang digunakan dalam minuman nya tahun itu. CEO Coca-Cola menganggap bahwa perusahaan penting untuk menjaga ekosistem air dan perusahaan untuk memmberikan kesejahteraan bagi masyrakat sekiatar (https://www.washingtonpost.com/news/e nergy-environment/wp/2016/08/30/cocacola-just-achieved-a-major-environmentalgoal-for-its-water- use $/$ ?noredirect $=$ on\&utm term $=. \mathrm{bfb} 19 \mathrm{~b} 3 \mathrm{c}$ ca8b diakses pada tanggal 29/09/2019).

Coca-cola yang konsen terhadap krisis air yang terjadi akibat dari produksinya melakukan konservasi air di Inonesia dengan membangun Embung. Coca-cola dengan dua waduk yang dibangun untuk menampung air hujan yang berlokasi di wilayah Jawa Tengah, yakni Kabupaten Karang Anyar dan Wonogiri. Selain memiliki fungsi konservasi air, embung seluas 1,5 hektar ini dapat menampung lebih dari 15 juta liter air dan juga berfungsi sebagai sumber irigasi bagi setidaknya 40 hektar perkebunan masyarakat atau 10 hektar sawah pertanian. Secara global, The Coca-Cola Company memiliki Visi Global 2020 untuk terkait Water Neutrality, dimana perusahaan akan mengembalikan air kembali ke alam dan masyarakat sama dengan jumlah air yang terpakai didalam produk dan pada proses produksi. CocaCola Indonesia menjadi salah satu negara pertama di dunia yang melampaui visi Water Neutral ini, dimana sejak tahun 2015, Indonesia telah mencapai angka $164 \%$ dalam hal water replanisement (https://www.cocacola.co.id/cerita/dukung -konservasi-air-coca-cola-bangun-embung diakses pada tanggal 29/09/2019).

\section{Kesimpulan dan Rekomendasi}

Permasalahan global menjadi konsen semua aktor internasional, salah satunya ialah perubahan iklim. Untuk mengatasi perubahan iklim tersebut negara, IGO, $\mathrm{NGO}$, MNC dan Individu memiliki peran penting. MNC sebagai yang memiliki peran penting dalam hal ini untuk mengatasi perubahan iklim cara yang dilakukan ialah sebagai aktor sponsor maupun investasi. 
Coca-Cola sebagai MNC berupaya untuk mengatasi perubahan iklim dengan menjadi sponsor dan berinvestasi, selain itu itu juga mendirikan rumah untuk daur ulang libah botol plastik yang disebabkan olehnya.

Melalui teori dan konsep yang ada bahwasanya perubahan iklim dinegosiasikan dalam COP21 di Paris, sehingga terbentuk prinsip-aturan dan norma yang dilakukan untuk mengatasi perubahan iklim, sehingga pada akhirnya sebagai landasan untuk mengatasi perubahan iklim, bisa disebuat rezim internasional. Coca-cola ikut serta dalam proses diplomasi lingkungan, namun hanya sebatas memberikan dukungan dan penekanan agar perusahaan multinasional lain untuk menggunakan paris agreement sebagai landasar revolusi terhadap bisnis, sehingga akan terbangun perkekonmian yang ramah lingkungan.

\section{Daftar Pustaka}

Agestu, I. (2014, Desember 3). Negara Berkembang Terkena Dampak Paling Parah Perubahan Iklim. Retrieved from $\mathrm{CNN}$ Indonesia: https://www.cnnindonesia.com/inter nasional/20141203012548-13415419/negara-berkembang-terkenadampak-paling-parah-perubahaniklim?

Bakry, U. S. (2017). Dasar-Dasar Hubungan Internasional. Depok: Kencana.

Coca-Cola et l'économie circulaire : Infinéo recycle les déchets en matières premières. (2015, Juni 11).
Retrieved from coca-cola-france.fr: https://www.coca-cola-

france.fr/stories/Coca-Cola-et-leconomie-circulaire

Editor. (2010, Maret 18). The company's commitment to the environment focuses on recycling and water management. Retrieved from mnn.com:

https://www.mnn.com/money/sustain able-business-practices/stories/cocacola-and-the-environment

Editor. (2016, Januari 16). Penyebab Perubahan Iklim dan Pemanasan Global. Retrieved from Lingkunganhidup.co: https://lingkunganhidup.co/penyebab -perubahan-iklim-pemanasanglobal/

Elysees, L. M. (2015, Desember 8). COP21: An Unmissable Opportunity In The Fight Against Climate Change. Retrieved from cokecce.com:

https://www.cokecce.com/news-andevents/news/cop21-an-unmissableopportunity-in-the-fight-againstclimate-change

Firmansyah. (2015, Desember 13). Beberapa Kesepakatan Konferensi Perubahan Iklim Paris. Retrieved from Kompas.com: https://internasional.kompas.com/re ad/2015/12/13/09090031/Beberapa. Kesepakatan.Konferensi.Perubahan. Iklim.Paris

Foley, G. (1993). Pemanasan Global, Siapakah yang Merasa Panas? Jakarta: Obor Indonesia. 
Hardcastle, J. L. (2015, Desember 7). COP21 Roundup: Schneider Electric, Acciona, BMW, Coca-Cola, Unilever, Elon Musk. Retrieved from environmentalleader.com:

https://www.environmentalleader.co m/2015/12/cop21-roundupschneider-electric-acciona-bmwcoca-cola-unilever-elon-musk/

Harvey, C. (2016, Agustus 30). Coca-Cola just achieved a major environmental goal for its water use. Retrieved from Washingtonpost.com:

https://www.washingtonpost.com/ne ws/energyenvironment/wp/2016/08/30/cocacola-just-achieved-a-majorenvironmental-goal-for-its-wateruse/?noredirect $=$ on\&utm_term $=. b f b$ $19 b 3 c c a 8 b$

Jäger, K. (2015, November 30). Dampak Perubahan Iklim Sudah Landa Dunia. Retrieved from dw.com: https://www.dw.com/id/dampakperubahan-iklim-sudah-landadunia/g-18873686

Mohan, A. M. (2009, Maret 2009). Coke's carbon footprints are revealed. Retrieved from greenerpackage.com: https://www.greenerpackage.com/me trics_standards/coke\%E2\%80\%99s_ carbon_footprints_are_revealed

Murdiyarso, D. (2003). Protokol Kyoto : Implikasi bagi Negara Berkembang. Jakarta: Kompas.

O'Dochartaigh, A. (2015, Desember 2). Multinational corporations important players in the background of COP21. Retrieved from The Irish Times: https://www.irishtimes.com/opinion/ multinational-corporationsimportant-players-in-thebackground-of-cop21-1.2450573

Parikesit, A. G. (2015, November 30). Sepuluh Negara Penghasil Emisi Karbon Dioksida Terbesar. Retrieved from $\quad \mathrm{NNN}$ Indonesia: https://www.cnnindonesia.com/inter nasional/20151130171044-13794992/sepuluh-negara-penghasilemisi-karbon-dioksida-terbesar?

Prambudianto, A. (2011). Diplomasi LIngkungan Teori dan Fakta. Jakarta: UI Press.

Ratifikasi Negara-Negara Peserta Paris Agreement diakses dalam https://treaties.un.org/doc/Publicatio n/MTDSG/Volume\%20II/Chapter\% 20XXVII/XXVII-7-d.en.pdf (22/02/2017 pkl 15:31 WIB)

RI, D. (2009). Undang-Undang Republik Indonesia Nomor 31 Tahun 2009 tentang Meteorologi, Klimatologi, dan Geofisika, Pasal 1 Ayat 18. Retrieved from dpr.go.id: www.dpr.go.id/dokjdih/document/uu/ UU_2009_31.pdf

Rudy, T. M. (1993). Administrasi dan Organisasi Internasional. Bandung: Refika Aditama.

Sandrine Dixson-Decleve and Hubert Patricot. (2015, Desember 10). COP21: How Will We Collaborate After Paris? Retrieved from cocacolacompany.com: https://www.cocacolacompany.com/stories/cop21thinking-about-how-will-wecollaborate-after-paris 
Senthilingam, M. (2016, Oktober). How climate change is affecting your health. Retrieved from lshtm.ac.uk: https://www.lshtm.ac.uk/research/res earch-action/features/how-climatechange-affecting-your-health

Sipayung, H. M. (2015, Desember 13). 195 negara setujui "Kesepakatan Paris". Retrieved from Antaranews.com: http://www.antaranews.com/berita/5 34820/195-negara-setujuikesepakatan-paris

Summary of the Paris Climate Change Conference. Paris, Prancis: Earth Negotiations Bulletin (ENB).

Tempo.co. (2016, April 22). Gelombang Panas di India, 1.826 Orang Tewas. Retrieved from Tempo.co: https://m.tempo.co/read/news/2016/0 4/22/118764955/gelombang-panasdi-india-1-826-orang-tewas

Timms, M. (2018, Maret 10). The relationship between corporations and climate change. Retrieved from worldfinance.com:

https://www.worldfinance.com/speci al-reports/the-relationship-betweencorporations-and-climate-change

WIbisono, M. (2015). Tantangan Diplomasi Multilateral. Jakarta: LP3ES.

Winarno, B. (2014). Dinamika Isu-Isu Global Kontemporer. Yogyakarta: CAPS (Center of Academic Publishing Service).

Winston, A. (2015, Desember 10). Why the Business World is Tackling Climate Change. Retrieved from Cocacolacompany.com: https://www.cocacolacompany.com/stories/Why-theBusiness-World-is-TacklingClimate-Change 


\section{LAMPIRAN}

\section{Lampiran 2.1}

\section{7. d) Paris Agreement}

\section{ENTRY INTO FORCE}

REGISTRATION:

STATUS:

TEXT:

\section{Paris, 12 December 2015}

4 November 2016, in accordance with article 21(1). The Agreement enters into force on the thirtieth day after the date on which at least 55 Parties to the Convention accounting in total for at least an estimated 55 per cent of the total global greenhouse gas emissions have deposited their instruments of ratification, acceptance, approval or accession.

4 November 2016, No. 54113.

Signatories: 195. Parties: 175.
C.N.63.2016.TREATIES-XXVII.7.d of 16 February 2016 (Opening for signature) and C.N.63.2016.TREATIES-XXVII.7.d of 16 February 2016 (Opening for signature) and
C.N.92.2016.TREATIES-XXVII.7.d of 17 March 2016 (Issuance of Certified True Copies).

Note: The Paris Agreement was adopted on 12 December 2015 at the twenty-first session of the Conference of the Parties to the United Nations Framework Convention on Climate Change held in Paris from 30 November to 13 December 2015. In accordance with its article 20, the Agreement shall be open for signature at the United Nations Headquarters in New York from 22 April 2016 until 21 April 2017 by States and regional economic integration organizations that are Parties to the United Nations Framework Convention on Climate Change.

\begin{tabular}{|c|c|c|c|c|c|c|c|}
\hline \multirow{2}{*}{$\begin{array}{l}\text { Participant } \\
\text { Afghanistan.. }\end{array}$} & Signature & \multicolumn{2}{|c|}{$\begin{array}{l}\text { Ratification, } \\
\text { Acceptance }(A), \\
\text { Approval }(A A), \\
\text { Accession }(a)\end{array}$} & \multirow{2}{*}{$\begin{array}{l}\text { Participant } \\
\text { Burkina Faso..... }\end{array}$} & Signature & \multicolumn{2}{|c|}{$\begin{array}{l}\text { Ratification, } \\
\text { Acceptance }(A), \\
\text { Approval }(A A), \\
\operatorname{Accession}(a)\end{array}$} \\
\hline & 2016 & $15 \mathrm{Feb}$ & 2017 & & 2016 & $11 \mathrm{Nov}$ & 2016 \\
\hline Albania............................ Apr & 2016 & 21 Sep & 2016 & Burundi ............................ Apr & 2016 & 17 Jan & 2018 \\
\hline Algeria & 2016 & 20 Oct & 2016 & Cabo Verde ......................... Apr & 2016 & 21 Sep & 2017 \\
\hline Andorra ............................ Apr & 2016 & $24 \mathrm{Mar}$ & 2017 & Cambodia......................... Apr & 2016 & $6 \mathrm{Feb}$ & 2017 \\
\hline Angola ............................ Apr & 2016 & & & Cameroon......................... Apr & 2016 & $29 \mathrm{Jul}$ & 2016 \\
\hline Antigua and Barbuda .....22 Apr & 2016 & 21 Sep & 2016 & Canada & 2016 & 5 Oct & 2016 \\
\hline Argentina .......................... Apr & 2016 & 21 Sep & 2016 & Central African & & & \\
\hline Armenia & 2016 & $23 \mathrm{Mar}$ & 2017 & Republic .....................22 Apr & 2016 & 11 Oct & 2016 \\
\hline Australia........................... Apr & 2016 & 9 Nov & 2016 & Chad ...................... & 2016 & 12 Jan & 2017 \\
\hline Austria $\ldots \ldots \ldots \ldots . . .22 \mathrm{Apr}$ & 2016 & 5 Oct & 2016 & Chile.......................... & 2016 & $10 \mathrm{Feb}$ & 2017 \\
\hline Azerbaijan....................... Apr & 2016 & 9 Jan & 2017 & China................................... Apr & 2016 & $3 \mathrm{Sep}$ & 2016 \\
\hline Bahamas.......................... Apr & 2016 & 22 Aug & 2016 & Colombia ...........................22 Apr & 2016 & & \\
\hline Bahrain............................ Apr & 2016 & 23 Dec & 2016 & Comoros..........................22 Apr & 2016 & 23 Nov & 2016 \\
\hline Bangladesh...................... Apr & 2016 & 21 Sep & 2016 & Congo................................... Apr & 2016 & $21 \mathrm{Apr}$ & 2017 \\
\hline Barbados ...................22 Apr & 2016 & $22 \mathrm{Apr}$ & 2016 & Cook Islands .......................24 Jun & 2016 & 1 Sep & 2016 \\
\hline Belarus ............................. Apr & 2016 & 21 Sep & $2016 \mathrm{~A}$ & Costa Rica........................... Apr & 2016 & $13 \mathrm{Oct}$ & 2016 \\
\hline Belgium ........................22 Apr & 2016 & $6 \mathrm{Apr}$ & 2017 & Côte d'Ivoire .....................22 Apr & 2016 & $25 \mathrm{Oct}$ & 2016 \\
\hline Belize & 2016 & $22 \mathrm{Apr}$ & 2016 & Croatia & 2016 & 24 May & 2017 \\
\hline Benin & 2016 & $31 \mathrm{Oct}$ & 2016 & Cuba................................ Apr & 2016 & $28 \mathrm{Dec}$ & 2016 \\
\hline Bhutan & 2016 & 19 Sep & 2017 & Cyprus............................. Apr & 2016 & 4 Jan & 2017 \\
\hline Bolivia (Plurinational & & & & Czech Republic..............22 Apr & 2016 & 5 Oct & 2017 \\
\hline State of) & 2016 & 5 Oct & 2016 & Democratic People's & & & \\
\hline Bosnia and & & & & Republic of Korea....22 Apr & 2016 & 1 Aug & 2016 \\
\hline Herzegovina ...............22 Apr & 2016 & $16 \mathrm{Mar}$ & 2017 & Democratic Republic of & & & \\
\hline Botswana ...................22 Apr & 2016 & $11 \mathrm{Nov}$ & 2016 & the Congo ...................22 Apr & 2016 & 13 Dec & 2017 \\
\hline Brazil ............................. Apr & 2016 & 21 Sep & 2016 & Denmark $^{1} \ldots \ldots \ldots \ldots \ldots \ldots \ldots . . .22$ Apr & 2016 & 1 Nov & $2016 \mathrm{AA}$ \\
\hline Brunei Darussalam ........22 Apr & 2016 & 21 Sep & 2016 & Djibouti .........................22 Apr & 2016 & 11 Nov & 2016 \\
\hline \multirow{2}{*}{ Bulgaria .............................. Apr } & 2016 & $29 \mathrm{Nov}$ & 2016 & Dominica ......................... Apr & 2016 & 21 Sep & 2016 \\
\hline & & & & Dominican Republic ......22 Apr & 2016 & 21 Sep & 2017 \\
\hline
\end{tabular}




\begin{tabular}{|c|c|c|c|}
\hline \multirow{2}{*}{$\begin{array}{l}\text { Participant } \\
\text { Ecuador........ }\end{array}$} & Signature & \multicolumn{2}{|c|}{$\begin{array}{l}\text { Ratification, } \\
\text { Acceptance }(A), \\
\text { Approval(AA), } \\
\text { Accession(a) }\end{array}$} \\
\hline & 2016 & 20 Sep & 2017 \\
\hline Egypt............. & 2016 & 29 Jun & 2017 \\
\hline El Salvador .... & 2016 & $27 \mathrm{Mar}$ & 2017 \\
\hline Equatorial Guinea ..........22 Apr & 2016 & & \\
\hline Eritrea ………………....... & 2016 & & \\
\hline Estonia ……..................... & 2016 & 4 Nov & 2016 \\
\hline Ethiopia........ & 2016 & $9 \mathrm{Mar}$ & 2017 \\
\hline European Union ..............22 Apr & 2016 & 5 Oct & 2016 \\
\hline Fiji & 2016 & $22 \mathrm{Apr}$ & 2016 \\
\hline 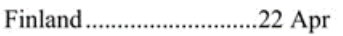 & 2016 & 14 Nov & 2016 \\
\hline France .......... & 2016 & 5 Oct & 2016 \\
\hline Gabon............. & 2016 & $2 \mathrm{Nov}$ & 2016 \\
\hline Gambia................ & 2016 & 7 Nov & 2016 \\
\hline Georgia .......... & 2016 & 8 May & $2017 \mathrm{AA}$ \\
\hline Germany ...... & 2016 & 5 Oct & 2016 \\
\hline 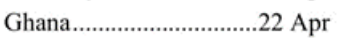 & 2016 & 21 Sep & 2016 \\
\hline Greece ................ & 2016 & $14 \mathrm{Oct}$ & 2016 \\
\hline Grenada................... & 2016 & $22 \mathrm{Apr}$ & 2016 \\
\hline Guatemala $\ldots \ldots \ldots \ldots \ldots \ldots \ldots \ldots . . .22 \mathrm{Apr}$ & 2016 & 25 Jan & 2017 \\
\hline Guinea......................... & 2016 & $21 \mathrm{Sep}$ & 2016 \\
\hline Guinea-Bissau........ & 2016 & & \\
\hline 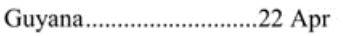 & 2016 & 20 May & 2016 \\
\hline Haiti ........................ & 2016 & $31 \mathrm{Jul}$ & 2017 \\
\hline Honduras.................... & 2016 & 21 Sep & 2016 \\
\hline Hungary ........................22 Apr & 2016 & 5 Oct & 2016 \\
\hline Iceland ............................ Apr & 2016 & 21 Sep & $2016 \mathrm{~A}$ \\
\hline India $\ldots \ldots \ldots$ & 2016 & 2 Oct & 2016 \\
\hline Indonesia $\ldots \ldots \ldots \ldots \ldots \ldots \ldots . .22 \mathrm{Apr}$ & 2016 & 31 Oct & 2016 \\
\hline $\begin{array}{l}\text { Iran (Islamic Republic } \\
\text { of) }\end{array}$ & 2016 & & \\
\hline Iraq....................... 8 Dec & 2016 & & \\
\hline Ireland ............................... & 2016 & 4 Nov & 2016 \\
\hline Israel ............................ & 2016 & 22 Nov & 2016 \\
\hline Italy .......................... & 2016 & $11 \mathrm{Nov}$ & 2016 \\
\hline Jamaica ………................ & 2016 & $10 \mathrm{Apr}$ & 2017 \\
\hline 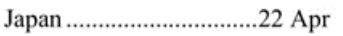 & 2016 & $8 \mathrm{Nov}$ & $2016 \mathrm{~A}$ \\
\hline Jordan ............................. & 2016 & 4 Nov & 2016 \\
\hline Kazakhstan...................... 2 Aug & 2016 & $6 \mathrm{Dec}$ & 2016 \\
\hline Kenya & 2016 & $28 \mathrm{Dec}$ & 2016 \\
\hline Kiribati............................ & 2016 & $21 \mathrm{Sep}$ & 2016 \\
\hline Kuwait ....................... Apr & 2016 & & \\
\hline Kyrgyzstan ........................ Sep & 2016 & & \\
\hline 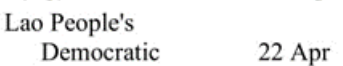 & 2016 & $7 \mathrm{Sep}$ & 2016 \\
\hline
\end{tabular}

\begin{tabular}{|c|c|c|c|}
\hline \multirow{3}{*}{ 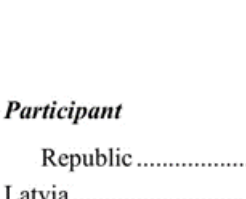 } & Signature & \multicolumn{2}{|c|}{$\begin{array}{l}\text { Ratification, } \\
\text { Acceptance }(A), \\
\text { Approval }(A A), \\
\text { Accession }(a)\end{array}$} \\
\hline & & & \\
\hline & 2016 & $16 \mathrm{Mar}$ & 2017 \\
\hline Lebanon ......... & 2016 & & \\
\hline Lesotho ........... & 2016 & $20 \mathrm{Jan}$ & 2017 \\
\hline Liberia..................... & 2016 & & \\
\hline Libya ............................ & 2016 & & \\
\hline Liechtenstein........ & 2016 & $20 \mathrm{Sep}$ & 2017 \\
\hline Lithuania ........... & 2016 & 2 Feb & 2017 \\
\hline Luxembourg..... & 2016 & $4 \mathrm{Nov}$ & 2016 \\
\hline Madagascar....... & 2016 & $21 \mathrm{Sep}$ & 2016 \\
\hline Malawi ............. & 2016 & 29 Jun & 2017 \\
\hline Malaysia...... & 2016 & $16 \mathrm{Nov}$ & 2016 \\
\hline Maldives ................ & 2016 & $22 \mathrm{Apr}$ & 2016 \\
\hline Mali....................... & 2016 & $23 \mathrm{Sep}$ & 2016 \\
\hline Malta ........................ & 2016 & 5 Oct & 2016 \\
\hline Marshall Islands... & 2016 & $22 \mathrm{Apr}$ & 2016 \\
\hline Mauritania.... & 2016 & $27 \mathrm{Feb}$ & 2017 \\
\hline Mauritius................ & 2016 & $22 \mathrm{Apr}$ & 2016 \\
\hline Mexico ............................ Apr & 2016 & $21 \mathrm{Sep}$ & 2016 \\
\hline cronesia (Federated & & & \\
\hline ....22 Apr & 2016 & 15 Sep & 2016 \\
\hline Monaco ........ & 2016 & 24 Oct & 2016 \\
\hline Mongolia............... & 2016 & $21 \mathrm{Sep}$ & 2016 \\
\hline Montenegro.......... & 2016 & $20 \mathrm{Dec}$ & 2017 \\
\hline Morocco............. & 2016 & $21 \mathrm{Sep}$ & 2016 \\
\hline Mozambique ....... & 2016 & & \\
\hline Myanmar...... & 2016 & 19 Sep & 2017 \\
\hline Namibia ............. & 2016 & $21 \mathrm{Sep}$ & 2016 \\
\hline Nauru .......................... & 2016 & $22 \mathrm{Apr}$ & 2016 \\
\hline Nepal................... & 2016 & 5 Oct & 2016 \\
\hline Netherlands ${ }^{2} \ldots \ldots \ldots . .$. & 2016 & $28 \mathrm{Jul}$ & $2017 \mathrm{~A}$ \\
\hline New Zealand ${ }^{3} \ldots \ldots \ldots \ldots \ldots . . .22 \mathrm{Apr}$ & 2016 & 4 Oct & 2016 \\
\hline Nicaragua ............................. & & 23 Oct & 2017 a \\
\hline Niger ............... & 2016 & $21 \mathrm{Sep}$ & 2016 \\
\hline Nigeria ....... & 2016 & 16 May & 2017 \\
\hline Niue ........... & 2016 & 28 Oct & 2016 \\
\hline Norway ....................... & 2016 & 20 Jun & 2016 \\
\hline Oman ....................... & 2016 & & \\
\hline Pakistan..... & 2016 & $10 \mathrm{Nov}$ & 2016 \\
\hline Palau ............ & 2016 & $22 \mathrm{Apr}$ & 2016 \\
\hline Panama........................... Apr & 2016 & $21 \mathrm{Sep}$ & 2016 \\
\hline Papua New Guinea ........22 Apr & 2016 & 21 Sep & 2016 \\
\hline Paraguay …….................... Apr & 2016 & 14 Oct & 2016 \\
\hline ……..........22 Apr & 2016 & $25 \mathrm{Jul}$ & 2016 \\
\hline
\end{tabular}




\begin{tabular}{|c|c|c|c|}
\hline \multirow{2}{*}{$\begin{array}{l}\text { Participant } \\
\text { Philippines .. }\end{array}$} & Signature & \multicolumn{2}{|c|}{$\begin{array}{l}\text { Ratification, } \\
\text { Acceptance }(A), \\
\text { Approval }(A A), \\
\operatorname{Accession}(a)\end{array}$} \\
\hline & 2016 & $23 \mathrm{Mar}$ & 2017 \\
\hline$\ldots 22 \mathrm{Apr}$ & 2016 & 7 Oct & 2016 \\
\hline Portugal........... $22 \mathrm{Apr}$ & 2016 & 5 Oct & 2016 \\
\hline Qatar & 2016 & 23 Jun & 2017 \\
\hline Republic of Korea...........22 Apr & 2016 & 3 Nov & 2016 \\
\hline Republic of Moldova .....21 Sep & 2016 & 20 Jun & 2017 \\
\hline Romania & 2016 & 1 Jun & 2017 \\
\hline Russian Federation ........22 Apr & 2016 & & \\
\hline Rwanda & 2016 & 6 Oct & 2016 \\
\hline Samoa & 2016 & $22 \mathrm{Apr}$ & 2016 \\
\hline San Marino ….................. Apr & 2016 & & \\
\hline Sao Tome and Principe..22 Apr & 2016 & 2 Nov & 2016 \\
\hline Saudi Arabia ................. $3 \mathrm{Nov}$ & 2016 & 3 Nov & 2016 \\
\hline Senegal................ $22 \mathrm{Apr}$ & 2016 & $21 \mathrm{Sep}$ & 2016 \\
\hline Serbia & 2016 & $25 \mathrm{Jul}$ & 2017 \\
\hline Seychelles ............. & 2016 & $29 \mathrm{Apr}$ & 2016 \\
\hline Sierra Leone.....................22 Sep & 2016 & 1 Nov & 2016 \\
\hline Singapore ......................... Apr & 2016 & 21 Sep & 2016 \\
\hline Slovakia ..................... & 2016 & 5 Oct & 2016 \\
\hline 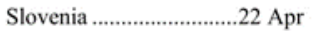 & 2016 & 16 Dec & 2016 \\
\hline Solomon Islands ............22 Apr & 2016 & 21 Sep & 2016 \\
\hline Somalia ...................... & 2016 & $22 \mathrm{Apr}$ & 2016 \\
\hline South Africa............. & 2016 & 1 Nov & 2016 \\
\hline South Sudan........... & 2016 & & \\
\hline Spain & 2016 & 12 Jan & 2017 \\
\hline Sri Lanka.............................. Apr & 2016 & 21 Sep & 2016 \\
\hline St. Kitts and Nevis .........22 Apr & 2016 & $22 \mathrm{Apr}$ & 2016 \\
\hline St. Lucia............................ Apr & 2016 & $22 \mathrm{Apr}$ & 2016 \\
\hline $\begin{array}{l}\text { St. Vincent and the } \\
\text { Grenadines............... }\end{array}$ & 2016 & 29 Jun & 2016 \\
\hline State of Palestine ….......22 Apr & 2016 & $22 \mathrm{Apr}$ & 2016 \\
\hline Sudan & 2016 & 2 Aug & 2017 \\
\hline Suriname & 2016 & & \\
\hline Swaziland.................. & 2016 & $21 \mathrm{Sep}$ & 2016 \\
\hline
\end{tabular}

\begin{tabular}{|c|c|c|c|}
\hline \multirow{2}{*}{$\begin{array}{l}\text { Participant } \\
\text { Sweden......... }\end{array}$} & Signature & \multicolumn{2}{|c|}{$\begin{array}{l}\text { Ratification, } \\
\text { Acceptance }(A), \\
\text { Approval }(A A), \\
\text { Accession }(a)\end{array}$} \\
\hline & 2016 & $13 \mathrm{Oct}$ & 2016 \\
\hline Switzerland ......... & 2016 & 6 Oct & 2017 \\
\hline Syrian Arab Republic .... & & 13 Nov & 2017 a \\
\hline Tajikistan ............................ Apr & 2016 & $22 \mathrm{Mar}$ & 2017 \\
\hline Thailand ........................ Apr & 2016 & 21 Sep & 2016 \\
\hline $\begin{array}{l}\text { The former Yugoslav } \\
\text { Republic of } \\
\text { Macedonia................22 Apr }\end{array}$ & 2016 & 9 Jan & 2018 \\
\hline Timor-Leste …_............ $22 \mathrm{Apr}$ & 2016 & 16 Aug & 2017 \\
\hline Togo & 2016 & 28 Jun & 2017 \\
\hline Tonga & 2016 & 21 Sep & 2016 \\
\hline Trinidad and Tobago .....22 Apr & 2016 & $22 \mathrm{Feb}$ & 2018 \\
\hline Tunisia & 2016 & $10 \mathrm{Feb}$ & 2017 \\
\hline Turkey............................ Apr & 2016 & & \\
\hline Turkmenistan ..................... Sep & 2016 & $20 \mathrm{Oct}$ & 2016 \\
\hline Tuvalu ............................ Apr & 2016 & $22 \mathrm{Apr}$ & 2016 \\
\hline Uganda ........................... $\mathrm{Apr}$ & 2016 & 21 Sep & 2016 \\
\hline Ukraine & 2016 & 19 Sep & 2016 \\
\hline United Arab Emirates ....22 Apr & 2016 & $21 \mathrm{Sep}$ & $2016 \mathrm{~A}$ \\
\hline $\begin{array}{l}\text { United Kingdom of } \\
\text { Great Britain and } \\
\text { Northern Ireland.......22 Apr }\end{array}$ & 2016 & $18 \mathrm{Nov}$ & 2016 \\
\hline $\begin{array}{l}\text { United Republic of } \\
\quad \text { Tanzania.................... Apr }\end{array}$ & 2016 & & \\
\hline $\begin{array}{l}\text { United States of } \\
\quad \text { America.................... }\end{array}$ & 2016 & 3 Sep & $2016 \mathrm{~A}$ \\
\hline Uruguay …...................... Apr & 2016 & 19 Oct & 2016 \\
\hline Uzbekistan ..................... Apr & 2017 & & \\
\hline Vanuatu................... Apr & 2016 & 21 Sep & 2016 \\
\hline $\begin{array}{l}\text { Venezuela (Bolivarian } \\
\quad \text { Republic of) ..............22 Apr }\end{array}$ & 2016 & $21 \mathrm{Jul}$ & 2017 \\
\hline Viet Nam.................. Apr & 2016 & 3 Nov & $2016 \mathrm{AA}$ \\
\hline Yemen $\ldots \ldots . .23$ Sep & 2016 & & \\
\hline Zambia & 2016 & $9 \mathrm{Dec}$ & 2016 \\
\hline Zimbabwe ......................22 Apr & 2016 & 7 Aug & 2017 \\
\hline
\end{tabular}

Declarations

(Unless otherwise indicated, the declarations were made upon ratification, acceptance, approval or accession.)

BELGIUM

"This signature engages also the Walloon Region, the Flemish Region and the Brussels-Capital Region.

$$
\text { BULGARIA }
$$

"The Republic of Bulgaria recognizes that in accordance with Article 9, paragraph 1, of the Paris
Agreement developed country Parties shall provide financial resources to assist developing country Parties with respect to both mitigation and adaptation in continuation of their existing obligations under the Convention. In this context the Republic of Bulgaria notes that as a Party to the United Nations Framework Convention on Climate Change Bulgaria is not included
in Annex II." 
China

In accordance with the Basic Law of the Hong Kong Special Administrative Region of the People's Republic of China and the Basic Law of the Macao Special the Government of the People's Republic of Chin decides that the Agreement applies to the Hong Kon Special Administrative Region and the Macao Specia Administrative Region of the People's Republic of China.

\section{COOK ISLANDS}

The Government of the Cook Islands declares its understanding that acceptance of the Paris Agreement and its application shall in no way constitute a renunciation of any rights under international law concerning State responsibility for the adverse effects of climate change and that no provision in the Paris Agreement can be and that no provision in the Paris Agreement can be international law or any claims or rights concerning compensation due to the impacts of climate change.

The Government of the Cook Islands further declares that, in light of the best available scientific information and assessment on climate change and its impats, it considers the omissions reduction andigations in considers the enissiment to be in global temperare stabilisation level at or above 1.5 global temperature stabilisation level at or above 1.5 degrees Celsius relative to pre-industrial levels and as implications for our national interests.

EUROPEAN UNION

"Declaration by the Union made in accordance with Article 20(3) of the Paris Agreement

The following States are at present Members of the European Union: the Kingdom of Belgium, the Republic of Bulgaria, the Czech Republic, the Kingdom of Denmark, the Federal Republic of Germany, the Republic Denmark, the of Spain, the French Republic the Republic of Crotia, 年,

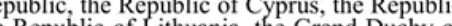
, Luxembourg, Hungary, thepublic of Malta, the Kingdom of the Republic of Poland, the Portuguese Republic, Romania, the Republic of Slovenia, the Slovak Republic, the Kingdom of Great Britain and Northern Ireland.

The European Union declares that, in accordance with the Treaty on the Functioning of the European Union, and in particular Article 191 and Article 192(1) thereof, it is competent to enter into international agreements, and to contribute to the pursuit of the following objectives:

- preserving, protecting and improving the quality of the environment;

- protecting human health;

- prudent and rational utilisation of natural resources;

promoting measures at international level to deal with regional or worldwide environmental problems, and in particular combating climate change. The European Union will continue to provide
information, on a regular basis on any substantial information, on a regular basis on any substantial
modifications in the extent of its competence, in modifications in the extent of its competenc
INDIA

"The Government of India declares its understanding that, as per its national laws; keeping in view its development agenda, particularly the eradication of poverty and provision of basic needs for all its citizens, coupled with its commitment to following the low carbon path to progress, and on the assumption of unencumbered availability of cleaner sources of energy and technologies and financial resources from around the world; and based on a fair and ambitious assessment of global commitment to combating climate change, it is ratifying the Paris Agreement."

\section{MARSHALL ISLANDS}

"...the Government of the Republic of the Marshall Islands declares its understanding that ratification of the Paris Agreement shall in no way constitute a renunciation of any rights under any other laws, including international of any rights under any other laws, including international
law, and the communication depositing the Republic's instrument of ratification shall include a declaration to this effect for international record;

FURTHERMORE, the Government of the Republic of the Marshall Islands declares that, in light of best scientific information and assessment on climate change and its impacts, it considers the emission reduction and its impacts, it considers the emission reduction obligations in Article 3 of the Kyoto Protocol, the Doha Amendment and the aforesaid Paris Agreement to be inadequate to prevent global temperature increase of 1.5 degrees Celsius above pre-Industrial levels and as a national interests..,

\section{Mexico}

in accordance with their national legal framework, and in consideration of the best and most up-to-date scientific information available and incorporated by the scientific information available and incorporated by the Intergovernmental Panel on Climate Change, the United Mexican States understands greenhouse gas emissions to mean the release into the atmosphere of greenhouse gases and/or their precursors and aerosols into the atmosphere, within a specific area and during a specific period of time.

\section{Micronesia (FEderated States of)}

"The Government of the Federated States of Micronesia declares its understanding that its ratification of the Paris Agreement does not constitute a renunciation of any rights of the Government of the Federated States of Micronesia under international law concerning State responsibility for the adverse effects of climate change, and that no provision in the Paris Agreement can be interpreted as derogating from principles of general international law or any claims or rights concerning compensation and liability due to the adverse effects of climate change; and

The Government of the Federated States of Micronesia further declares that, in light of the best available scientific information and assessments on climate change and its impacts, it considers the emission reduction obligations in the Paris Agreement to be inadequate to prevent a global temperature increase above 1.5 degrees Celsius relative to pre-industrial levels, and as a consequence, such emissions will have severe implications for the national interests of the Government

\section{NAURU}

“.. the Government, of Nauru declares its understanding that the ratification of the Agreement shall in no way constitute a renunciation of any rights under international law concerning State responsibility [for] the FURTHER

FURTHER, the Government of Nauru declares that no provisions in the Agreement can be interpreted as 
instrument of ratification shall include a declaration to this effect for international record;

FURTHERMORE, that the Government of the Republic of Vanuatu declares that, in light of best scientific information and assessment on climate change
and its impacts, it considers the emission reduction obligations in Article 3 of the Kyoto Protocol, the Doha Amendment and the aforesaid Paris Agreement to be inadequate to prevent global temperature increase of 1.5 degrees Celsius above pre-Industrial levels and as a consequence, will have severe implications for our national interests..."

\footnotetext{
Notes:

With territorial exclusion in respect of Greenland. Se C.N.819.2016.TREATIES-XXVII.7.d of 1 November 2016

2 For the European Part of the Netherlands.

3 On 13 November 2017, New Zealand notified the Secretary-General of the extention of the application of the Agreement to Tokelau (See CN.705.2017.TREATIESXXVII.7.d of 13 November 2017).

Upon ratification on 4 October 2017, New Zealand notified the Secretary-General of a territorial exclusion in respect of Tokelau (See C.N.723.2016.TREATIES-XXVII.7.d of 4 October 2016.)
} 